University of South Carolina

Scholar Commons

1998

\title{
The Transmission of the 'Digby' Corpus of Bilingual Glosses to Aldhelm's Prosa de virginitate
}

Scott Gwara

University of South Carolina - Columbia

Follow this and additional works at: https://scholarcommons.sc.edu/engl_facpub

Part of the English Language and Literature Commons

\section{Publication Info}

Published in Anglo-Saxon England, Volume 27, 1998, pages 139-168.

Gwara, S. (1998). The transmission of the 'Digby' corpus of bilingual glosses to Aldhelm's Prosa de virginitate. Anglo-Saxon England, 27, 139-168.

(CAnglo-Saxon England 1998, Cambridge University Press

This Article is brought to you by the English Language and Literatures, Department of at Scholar Commons. It has been accepted for inclusion in Faculty Publications by an authorized administrator of Scholar Commons. For more information, please contact digres@mailbox.sc.edu. 


\title{
The transmission of the 'Digby' corpus of bilingual glosses to Aldhelm's Prosa de virginitate
}

\author{
SCOTT GWARA
}

Aldhelm of Malmesbury's Prosa de virginitate (hereafter Pdv)' can be called one of the most enduring works of Anglo-Saxon scholarship. ${ }^{2}$ Immensely influential in Aldhelm's lifetime, the text continued to be popular in England and on the Continent until Viking invasions put an end to native learning in the last half of the ninth century. ${ }^{3}$ Yet by the 920 s interest in Aldhelm's prose treatise had revived, inaugurating a new movement in 'hermeneutic' Latin that lasted, in some centres, beyond the turn of the twelfth century. ${ }^{4}$ Fourteen English manuscripts of Pdv document the renewed interest in Aldhelm's work. Most of these manuscripts are heavily glossed, and, indeed, some preserve about 25,000 bilingual annotations ranging from single letters or symbols to entire paragraphs copied verbatim from Isidore's Etymologiae. The density of glossing is astounding, when contrasted with the length of $P d v$, about 20,000 words.

I I use the following abbreviations: Ehwald = R. Ehwald, Aldhelmi Opera, MGH, Auct. Antiq. 15 (Berlin, 1913-19); Goossens = L. Goossens, The Old English Glosses of M.S. Brussels, Royal Library 1650 (Aldhelm's De Laudibus Virginitatis) (Brussels, 1974); Gwara = S. Gwara, 'Literary Culture in Late Anglo-Saxon England and the Old English and Latin Glosses to Aldhelm's Prosa de virginitate', 2 vols. (unpubl. $\mathrm{PhD}$ dissertation, Univ. of Toronto, 1993); Isid. = Isidori Hispalensis ety'mologiarum sive originum libri XX, ed. W. M. Lindsay (Oxford, 1911); Ker = N. R. Ker, Catalogue of Manuscripts Containing Anglo-Saxxon (Oxford, 1957); Lapidge and Herren = M. Lapidge and M. Herren, Alabelm: the Prose Works (Cambridge, 1979); Lapidge and Rosicr = M. Lapidge and J. Rosier, Aldhelm: the Poetic Works (Cambridge, 1985); Napier = A. Napier, Old English Glosses, Chieffy Unpublished (Oxford, 1900). All citations of giosses derive from my edition.

${ }^{2} P d v$ was arguably composed in the 670s. The details of Aldhelm's biography derive mainly from William of Malmesbury's De gestis pontificum anglorum (ed. N. E. S. A. Hamilton, RS 52 (London, 1870)) in which bk V (pp. 330-443) comprises the Vita Aldhelmi. For a full overview of Aldhelm's career - his birth, education, travel, ecclesiastical honours and death - see Lapidge and Herren, pp. 5-10 as well as Lapidge and Rosier, pp. 5-9.

${ }^{3}$ See, for example, the Index locorum (II. Loci classici et ecclesiastici) to Ehwald, pp. 544-6; Lapidge's Appendix III ('Check-List of Sources of Aldhelm's Exemplary Virgins', Lapidge and Herren, pp. 176-8); T. J. Brown, 'An Historical Introduction to the Use of Classical Latin Authors in the British Isles from the Fifth to the Eleventh Century', SettSpol 22 (1975), 237-93, and, most recently, A. Orchard, The Poetic Art of Aldbelm (Cambridge, 1994) and idem, 'After Aldheim: the Teaching and Transmission of the Anglo-Latin Hexameter', Jnl of Med. Latin 2 (1992), 96-133.

4 Cf. S. Gwara, 'The Continuance of Aldhelm Studies in Post-Conquest England and Glosses to the Prosa de virginitate in Hereford, Cath. Lib. MS P.I.17', Semptoriwm 48 (1994), 18-38. On the hermeneutic idiom, cf. M. Lapidge, 'The Hermeneutic Style in Tenth-Century Anglo-Latin Literature', ASE 4 (1975), 67-111. 


\section{Scott Gwara}

Even after a century of research, discovering the transmission of such a large corpus of interrelated glosses remains problematical. Yet the transmission is central to Aldhelm studies: isolating the dissemination of glosses to $P d v$ means tracing the path of the Aldhelm revival as well as the origin of the hermeneutic Latin renaissance. ${ }^{5}$ In my view, untangling the knotty relationships between so many layers of $P d v$ glosses should be tackled manuscript by manuscript. Hence, I aim here to discuss certain gloss strata in three $P d v$ copies preserving the most bilingual glosses: Oxford, Bodleian Library, Digby 146, Brussels, Bïbliothèque Royale, 1650 and London, British Library, Royal 6 B. VII. Old English glosses in Brussels 1650 were first printed in $18300^{6}$ Vernacular glosses in Digby 146 and Royal 6. B. VII have been in print since 1900, when Arthur Napier published a substantial edition of Old English Pdv scholia. But even though thousands of Latin glosses circulated side-byside with the Old English ones and were often written by the same scribe, editors have ignored their relevance for more than 150 years. When the Latin glosses in these manuscripts are considered as part of the transmission histury, a new relationship emerges between these key $P d \nu$ witnesses. This new relationship not only documents the pre-eminence of Digby 146 as a source of Aldhelm scholarship but also discloses the conservative preservation of glosses to Pdv?

${ }^{3}$ Cf. S. Gwara, 'Manuscripts of Ndhelm's Prosa de virginilate and the Rise of Hermeneutic Literacy in Tenth-Century England', S:M, 3rd ser. 35 (1994), 101-59.

- F. Mone, Qwellen und Forschungen ₹ar Geschicble der tewtschen Literatur und Spracbe I (Aachen, 1830) pp. $329-442$.

7 Hereafter I refer to manuscripts by sigla according to the following list. My sigla differ from Ehwald's (p. 225) in some respects. A denotes the Yale fragment to which Ehwald had given two sigla: frgt. Oxon. =Bodl. Lib. MS th. d. 24, fols. 1-2; $P=C$ ambr. Add. 3330. In my apparatus P denotes the Hereford Pdv copy, rather than Harley 3013, to which Ehwald assigned no siglum. The London fragment has been incorrectly cited in a number of sources as Add 50483K, but re-catalogued as of 1997.

R2 London, BL, Royal 7. D. XXIV, 82r-168r: text s. $x^{1}$, gll. s $x^{2}$, ?Glastonbury, ?Canterbury

R4 London, BL, Royal 5. E. XI: text s. $x / x i$, gll. s. $x^{i k}-x^{m}{ }^{n t}$; Christ Chutch, Canterbury

S Salisbury, Carhedral I.ibrary, 38: text, gll. s. $x^{\mathrm{en}}$; Christ Church, Canterbury

C1 Cambridge, Corpus Christi College 326: text s. $x^{2}, g^{l l} .5 . x^{2}-x i^{i n}$; Christ Church, Canterbury

C2 Oxford, Bodleian Library, Bodley 97: text, gll. s. xim, Christ Church, Canterbury

A Cambridge, University Library, Add. 3330+

New Haven, Yale Liniversity, Beinecke Library 401, 401A+

London, $\mathrm{BI}$, Add. $71687+$

London, BL, Add. 50483y+

Oxford, Bodleian, Arch. A. fol. 131

Oxford, Bodleian, th. d. 24 , fols. 1-2+

Coll. Martin Schøyen MS 187 (olim Aachen, Dr Peter Ludwig's Library; Malibuf. Paul Getry Museum Ludwig XI 5)+

Philadelphia, Free L.sbrary, John Frederick Lewis Coll. ET 121: text s. ixing gll. s. $x^{2}$, ?Glastonbury, ?Canterbury

P Hereford, Cathedral Library, P. I. 17: text, gil. s. xii/xiii; ?Abingdon, Cirencester

The dates, origins and provenances of these manuscripts are discussed in Gwara 1, Pp. xxxvii-clvi. 
THREE GLOSSED MANUSCRIPTS OF PDV

Oxford, Bodleian Library, Dighy 146 (S.C. 1747) (O)

The Digby volume contains Pdv (fols. 1-95), Aldhelm's Epistola ad Heabfridum $(95 \mathrm{v}-100 \mathrm{v})$, and a version of ci 1200 of King Edward's martyrdom $(101 \mathrm{v}-104 \mathrm{r}){ }^{8}$ As an example of Style Il Anglo-Caroline, the Digby volume must have originated in late-tenth-century Canterbury. Although produced at Canterbury, Digby 146 migrated to Abingdon during its history. An early-sixteenth-century inscription appears on -1r:- Liber monast<er $>$ ii Abendonie quem Iohannes Clyffe fecit ligari $\mathrm{A}^{0} \ldots{ }^{10} \mathrm{~T}$ The date is now illegible. The volume was in the possession of Thomas Allen in 1622, but Sir Kenelm Digby donated it to the Bodleian a decade later. ${ }^{1}$

In Ker's view, the Old English Digby glosses can be divided into three groups according to scribe. ${ }^{12}$ Group (1) ${ }^{13}$ consists of about thirty giosses contemporaneous or virtually contemporaneous with the text and written at the same time as the first stratum of Latin glosses (s. $\left.x^{e y}\right) .^{14}$ These few glosses have peculiar affinities with the early layers in many $P d \nu$ manuscripts, notably London, British Library, Royal 7. D. XXIV.15 Ker's second group of glosses, Group (ii), comprises additions 'in a very neat and minute hand probably of $\mathrm{s}$. $\mathrm{xi}$ in. only on fols. $8-15{ }^{\prime}{ }^{16} \mathrm{Ker}$ concluded that these glosses were added after the main group of Latin glosses

- C. E. Fell, Edward King and Martyr (Leeds, 1971), pp. xix-xx and 1-16; cf. D. Rollason, The Cults of Murdered Royal Saints in Anglo-Saxon England', ASE 11 (1983), 1-22, at 2. The sheets are ruled dry-poinc, ruled nineteen lines ro the page. The collation is complex, and Quire III preserves an unusual cancellation: $\mathrm{I}^{2}$ (blank $)+\mathrm{II}^{\mathrm{B}}(3,5$ canc. $)+\mathrm{III}^{10}(4,5$ canc. $)+\mathrm{IV}^{\mathrm{a}}-\mathrm{XIII}^{\mathrm{s}}+\mathrm{XJV}^{\mathrm{s}}(8$ canc.) (end of $P d y+\mathrm{XV}^{3}\left(1,3,5,7\right.$ canc.) $+\mathrm{XVI}^{2}$ (a bifolium, blank).

- Curved elements in b, c, d, c, o, p and $q$ are rotund. Uinlike some cocval Canterbury scripes. however, Caroline a has no exaggerated top-stroke, and its back slants at $45^{\circ}$. Letter e has a neg. ligible compartment, $\mathbf{g}$ boasts a comparable compartment with a grand, sweeping cawda, resembling that in some scripts of St Augustine's. Although the Caroline element of the Digby seript dominates letter-forms, abbreviations and ligatures, the scribe srill tends to incorporate $\boldsymbol{x}$ in Latin, predominantly in final position. On the generic conventions of Style II Anglo-Caroline, cf. D. Dumville, Englisb Carotine Script and Monastic Hirtory (Woodbcidge, 1993).

10 According to Napier, John Clyfie or Clyve can be identified in Dugdale's Menasticon Anglicamum and Oxford University Register for 1510 (Napier, p. xiii). F.hwald miscranscribed the name as 'Clyssc' (Ehwaid, p. 219).

"A. Watson, Thomas Allen of Oxford and his Manuscripts", Medienal Smibes, Manuscripts and Libraries: Essays presented to N.R Ker, ed. M. Parkes and A. Watson (London, 1978), Pp. 279-314. ${ }_{12} \mathrm{Ker}$, no. 320.

13 I refer to Ker's 'Groups (i), (ii) and (iii)' as the products of 'scribes (i), (ii) and (iii)' or written in 'hands (i), (ii) and (iii)'. The cerms are meant to be equivalent.

I4 This hand is not identified in Napier's edition of the Old English glosses.

15 C. my discussion in 'Manuscripts'. Glosses from the first seven layers of Royal 7. D. XXIV ('Early Strata') form part of the first layer in Digby 146 (Ker's hand (i) and Napier's 'second Latin hand). The Digby text was in fact copied from an apograph of Royal 7. D. XXIV.

${ }^{16} \mathrm{Ker}, \mathrm{p} .382$. In fact, this hand continues on later folios, c.g. $16 \mathrm{r} 5$ (berebecri). 


\section{Scott Gwara}

but before the primary group of Old English glosses in his Group (iii). Few glosses in Group (ii), Ker mentions, have parallels in the Brusseis manuscript. A comparison of respective examples cited by Ker and Napier shows that this hand corresponds to Napier's 'Second Hand'. ${ }^{17}$ The third group of glosses disclosed by Ker's examination are the more than 5000 annotations 'on fols. 8-95 in a small and neat, but uncalligraphic hand, probably of s. xi med., which tends to slope either up or down the page. ${ }^{18}$ This hand corresponds to Napier's 'Ordinary Hand'. All the Old English glosses are written in Insular characters, except for some in the first layer and two in a twelfth-century script; these have an admixture of Insular and Caroline letter-forms, the latter being $\mathbf{a}, \mathrm{g}, \mathbf{r}$ and $\mathbf{s}$.

In his edition of 1974, Louis Goossens did not explore the palaeography of Digby 146, and neither he nor Ker expanded on Napier's brief discussion of the Latin glosses. Napier divided these into two main hands. The first, called by him the 'ordinary Latin hand', contributed the majority of interlinear and marginal Latin glosses. The ink is light brown, and strokes are executed with a narrow-cut pen. Ietters $\mathrm{m}, \mathrm{n}$ and $\mathrm{r}$ taper at the ends and sometimes even look sharp at their terminations.

Napier's 'second Latin hand' added vernacular glosses only infrequently. Napier did not realize that this hand is identical to Ker's scribe (i), who contributed the first layer of Old English glosses. This scribe writes a large pure AngloCaroline script in black ink. The Caroline letter-forms lack formal features, but the tails of a and $t$ occasionally curve upward at word-ends. Additionally, the scribe has made wide use of $\&$ for 'et'. Two punctus set off the abbreviations for id est and scilicet. According to Napier, the 'second Latin hand' ends at the bottom of $68 \mathrm{r}$, and the 'ordinary Latin hand' continues glossing thereafter. My own examination reveals that the 'second Latin hand' appears throughout the later portion of the volume intermittently after $68 \mathrm{r}$. No reason attributable to the manuscript explains why the marginal glossing should suddenly diminish here, and the change might reflect a defective exemplar or scribal caprice. ${ }^{19}$ Occasional Latin glosses, some with Insular letter-forms (such as r), were also penned by Ker's scribe (iii). Furthermore, Ker's scribe (ii) seems to have contributed a small layer of Latin glosses with an attenuated duct having tall, sharp ascenders and descenders. This expert Anglo-Caroline script still betrays Insular forms in a and r. Like Ker's scribe (ii), these glosses are later than the first

${ }^{17}$ Napier, p. xiii.

${ }_{18}$ Ker, p. 382. N2pier draws attention (p. xiii) to 'some few English glosses (which] have also been written... here and there by various different hands'. Thus urangaise (30v16) and ealswage (70v8) are twelfth-century additions.

19 For examplc, the glossing ends after the catalogue of male virgins and part-way into the list of female virgins. A monk might have deemed this part of the book less valuable or pertinent to his intended audience. 
The transmission of the 'Digby' glosses to Aldhelm's Prosa de virginitate stratum of Latin glosses, but come before the Old English glosses in Ker's hand (iii).

Brussels, Bibliosbique Royale, 1650 (olim 1580) (B)

Four scholars in this century have scrutinized and described the Brussels Pdv: G. Van Langenhove, N. R. Ker, R. Derolez and L. Goossens. ${ }^{20}$ My own remarks derive partly from the work of these scholars.

The Brussels Aldhelm is foliated $\mathrm{i}+56+\mathrm{i}$, collated I8- $\mathrm{VII}^{8}$; it measures $28 \times 44$ $\mathrm{cm}$, with a written space of $22.5 \times 15 \mathrm{~cm}$. Ruled in dry-point with twenty-two long lines per page, the manuscript was penned by a single scribe of $\mathrm{s} . \mathrm{xi}^{1}$ in a hand closely resembling the Style IV Anglo-Caroline from Canterbury in the second quarter of the eleventh century. ${ }^{21}$ The letter forms b, c, d, e, g, o, p, q are rotund. Upper and lower members of $\mathbf{g}$ are proportional and sometimes connected by a small stem; e has a narrow upper compartment, unlike a, which is well-formed with a large upper member. Common ligatures are rt, st and $\mathbf{r}+\mathbf{c c}$ form of a; \& is used freely, even with caudae representing 'aet' or e-caudata plus t. Chapter-headings are written in uncial, and syntactic glossing, probably in the main scribal hand, appears consistently.

Four principal and contemporaneous glossing hands of $\mathrm{s}$. $\mathrm{xi}^{1}$ appear in Brussels $1650 .{ }^{22}$ Ker's hand (1), a 'pointed, sloping' hand writing either in brown

20 Respectively, Aldbeln's De Lawdibus Vinginitatis with Latin and Old Fnglisb Glosser: Manuscript 1650 of the Rgyal Library in Brussels (Bruges, 1941); Ker, no. 8; De oudengelse Aldhelmglossen in HS. 1650 van de koninklijke Bibliotheek te Brussel', Handelingen LX der Zuidnederlandse Maatscbappij neor Taal- en I etterkande en Cescbiednis 1955, 37-50; Goossens, pp. 5-8, 28-32, 37-52.

21 The volume once belonged to a single codex of 242 folios comprising three items, but now broken up into four fragments. In addition to the Brussels portion there is: (a) Antwerp, PlantinMoretus Museum MS 47 (Salle iii.68) + (b) London, British Library, Add. 32246 [Ket 2]; (c) Antwerp, Plantin-Moretus Museum MS 190 (Salle iii.55) [Ker 3]. The flyleaves of these manuscripts contain additions of $\mathbf{y} . \mathrm{xi}^{\prime}$, which Ker used to localize the composite codex to Abingdon. Ker relied most heavily on forty-nine elegiac couplets by an unknown Herbert (of Fleury?) to Wulfgar, identified as abbot of Abingdon 989-1016 (ptd. E. Dümmler, 'Lateinische Gedichte des neunten bis elften Jahrhunderts'. Newes Arebiv 10 (1884), 351-3). Ker insisted that '[s]cholia to the Excurptiones, two supply-leaves .... the verses [to Wulfgar] and [two] glossaries .... are in a pointed, slightly forward-sloping hand which occurs also in [Brussels] $1650^{\circ}$ (Ker, p. 3). In other words, the carliest stratum of glosses in Brussels 1650 was written in the same hand as the verses to Wulfgat. Speculating that the elegiac verses were addressed to Wulfgat of Abingdon and further theorizing that the eleventh-century provenance of this manuscript was Abingdon, Ker could reach only one conclusion concerning the Brussels glosses: unless the scribe travelled from elsewhere, all of them must have been added at Abingdon. Unfortunately, Ker's rcasoning not only contradicts the palacographical record (cf. Dumville, Englisb Carolime, pp. 102, 136 and 154) but also makes no sense in the textual history of $P d v$ manuscripts which $I$ present here.

2 Goossens discusses the palacography in his volume (pp. 45-52), and I have not recorded all of his observations here. Hands A, B, C, CD and $\mathrm{R}$ appear in chronological order, except for $\mathrm{A}$ and $\mathrm{B}$. Scribes $\mathrm{A}$ and $\mathrm{B}$ never gloss the same words, so their relative chronology cannot be gauged by this formal method. Ker describes these hands in his Catalogue entry. 


\section{Scott Gwara}

(earlier) or black (later) ink, corresponds to Goossens's Hand A. This scribe may have preceded or followed another represented by Ker's hand (2), which Goossens calls Hand B. Ker describes this contribution as 'a small upright hand which occurs only about fols. 34-45'. There are few glosses in this hand. Goossens cautiously suggests that scribe (2) may have collaborated with scribe (1), but acknowledges that there is no evidence for the assumption except the divisions of their respective contributions in the Brussels volume. ${ }^{23}$ (The work of scribe A comes first.) Ker's hand (3) corresponds to Goossens's Hand C. In Ker's words, it is 'a spreading, slightly sloping hand, using rich brown ink, later than hand (1), but generally like it...'This glossator has taken lemmas from the text and glossed them in the outer margins, ${ }^{24}$ as if he were preparing glossae collec. tae for a glossary.

There are at least two different strata of glosses in Ker's hand (3), as distinguished by distinct shades of ink. Goossens first noted the variance. $\mathrm{He}$ described the first layer as dark brown to black, contributing the interlinear Old English glosses; the second layer, in a somewhat smaller format and in light brown ink, comprises the marginal glosses and most of the interlinear Latin ones. $^{25}$

Ker's hand (4), called CD in Goossens's edition, is at times difficult to distinguish from hand (3). In Ker's terms, it is a 'clumsy, square hand, using generally brown ink of poor quality'. Ker notes, too, that some glosses by this scribe are written in red ink, and Goossens describes these as the "last layer of the glossing'. ${ }^{26} \mathrm{CD}$ wrote almost no Latin glosses. Goossens paid careful attention to this hand, in which he was able to perceive the work of at least two and maybe more scribes. His appellation $C D$ is therefore intended to be a catch-all for various glossing contributions as distinct from those made by $\Lambda$ and $B-$ Ker's hands (1) and (2).

London, British Library, Rgyal 6. B. VII (RS)

This Royal manuscript ${ }^{27}$ preserves approximately 500 Old English glosses as wcll as thousands of Latin ones, almost all of which were written in the same semi-rotund Exeter hand as the text. The duct of the main hand in Royal 6. B. VII is relatively wide, with almost all circular elements in the letters b, c, d, g, o, $\mathrm{p}, \mathrm{q}$ perfectly round. On occasion the scribe clips the left-hand curve of these letters, giving a 'left-leaning' aspect. Characteristic of this main hand is a 'leftleaning' Caroline a with open upper member and correspondingly compressed

21 Goossens, p. 51. Goossens assumes that the seribes copied an exemplar.

24 Cf. R. Derolez, 'Zu den Brüsseler Aldhelmglosser', Anglia 74 (1957), 153-80.

${ }^{25}$ Goossens, p. $48 . \quad{ }^{26}$ Ker, p. 7; Goossens, p. 50.

$n$ Cf. G. Warner and J. Gilson, Catalogue of Western Manuscripts in the Old Rogal and King's Collections (Landon, 1921), p. 136. 
The transmission of the 'Digby' glosses to Aldhelm's Prosa de virginitate

lower member, rotund $\mathbf{e}$ with tiny upper compartment and angular crossstroke, negligible serifs on $\mathrm{m}$ and $\mathbf{n}$. Abbreviations and nomina sacra are infrequent, although regular in form. ${ }^{28}$ The script is purely calligraphic, a minuscule of the late eleventh century with distinct pen-lifts and highly mannered features (in particular st and $\mathbf{r t}$ ligatures, \&, and e-caudata). Although the elegant script, overall accuracy of text and care of execution imply that Royal 6. B. VII was a de Luxe copy of $P d v$, misplaced and erroneous glosses belie its superior production.

The identical script recurs in a gloss hand of Cambridge, Trinity College 315 (fols. 26-7, 36v12-39v1, from St Mary's Leicester) and in the main hand of Cambridge, Trinity College 1475 (a holograph). ${ }^{29}$ Generically resembling the style of more or less coeval Exeter manuscripts (such as London, BL, Cotton Cleopatra B. xiii or Cambridge, Corpus Christi College 191), the main Royal hand is nevertheless asymptomatic of the Leofrician script developed at the Exeter scriptorium. According to Elaine Drage, who catalogued all eleventhcentury Exeter books in her monumental Oxford thesis, 'the nucleus of [Royal 6. B. VII was probably written at Exeter towards the end of the eleventh century, since ... it is both more decorated than is usual for the bulk of "Exeter" manuscripts and the illuminated initials show affinities with those in books imported from Normandy to Exeter, probably by Bishop Osbern $(1072-1103)^{\prime} \cdot .^{\circ 0}$ The main hand of Royal 6. B. VII therefore represents the second generation of the Exeter house style.

Royal 6. B. VII has been ruled in dry-point with twenty-five long lines per page and collated by Drage before rebinding in 1983: (fols. $\mathrm{i}+1-53+\mathrm{i}+54-55+\mathrm{i}$ ), $\mathrm{I}^{8-} \mathrm{VI}^{8}$, VII ${ }^{6}$ (fols. 49-53+i), $\mathrm{VIII}^{3}$ (fols. 54, 55+i). The collation presently reads: $\mathrm{iii}+\mathrm{I}^{2}+\mathrm{II}^{6}+\mathrm{III}^{1}$ (a singleton) $+\mathrm{IV}^{8}-\mathrm{VII}^{8}+\mathrm{IX}^{1}$ (a singleton) $+\mathrm{X}^{4}$ (now all singletons) $+\mathrm{XI}^{1}$ (a singleton) $+\mathrm{XII}^{2}$ (a bifolium) + iiii. Now re-bound with individual quires sewn to paper guards, the book measures $30 \times 20 \mathrm{~cm}$, with a written area of $22 \times 15 \mathrm{~cm}$. Because the lines are so widely spaced and the glosses so carefully posicioned, the manuscript appears

7 These features arc, of course, characteristic of the script developed by the Canterbury scribe Eadwig Basan and practised at Christ Church from the second quarter of the eleventh century onwards. Eadwig's script appears in the Hanover Gospel Book (Hanover, Kestner-Museum, W. M. XXIa, 36) and in London, BL, Cotton Vespasian A. i, pt ii. By c. 1040 this Canterbury model was imitated in major scriptoria across southern England and formed the basis for the Exeter seript of Leofric's scriptorium. Even so, there are appreciable differences between the Exeter script and Eadwig's expcrimentations: Canterbury books often have a Canonical Capital display script, compressed lower member on a, and the tendency, apparent early at Tours, to link the upper fillips of letters across the bounding line.

* T. A. M. Bishop, 'Notes on Cambridge Manuscripts, Part III: MSS. Connected with Exeter', Trans. of the Cambridge Bibliograpbical Soc. 2 (1954-8), 192-9, at 198-9.

30 E. Drage, Bishop Leofric and the Excter Cathedral Chapter 1050-1072: a Reassessment of the Manuscript Evidence' (unpubl. D.Phil. dissertation, Oxford Univ., 1978), p. 372. 
to have been ruled for glossing. ${ }^{31}$ The volume was not catalogued in the Exeter inventory of 1327 , and its later history is virtually unknown. ${ }^{32}$

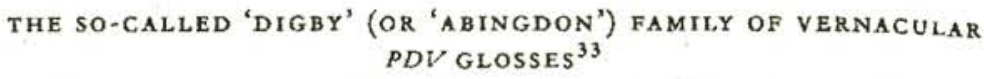

In the course of editing some 7,000 Old English glosses to $P d v$ for his compendium, Arthur Napier observed that hundreds of identical glosses appear in more than one manuscript. To account for the relationship between these glosses, Napier prefaced his edition with a theory of the gioss transmission. In a brief digression he reasoned that the vernacular glosses in seven manuscripts belong to two families, the 'Digby group' and the 'Salisbury group'. ${ }^{3+}$ To the 'Digby group' Napier assigned Brussels 1650, Digby 146, Royal 6. B. VII and Hereford, Cathedral Library P. I.17. Old English glosses in these books, he concluded, 'are closely related and ultimately come from one original'.15 In fact, Napier viewed the Old English glosses in Digby 146 as an apograph copy of those in a lost exemplar which he designated ' $\mathrm{Y}$. ${ }^{36}$ In his opinion, the Old English glosses in Brussels 1650 also derive from this exemplar. ${ }^{37}$ Napier alleged that glosses in the third manuscript of his 'Digby' family, Royal 6. B. VII, stem from a hyparchetype of ' $\mathrm{Y}$ ', or, in his terms, ' $\mathrm{X}$ '. ${ }^{38}$ This hyparchetype was 'presumably free from the Kenticisms characteristic of [Digby 146] and [Brussels $1650]^{3.39}$ Finally, Napier concluded that glosses in Hereford P. I.17 descended from those in Digby 146. ${ }^{\text {th }}$

Working from the advantage of shared error in his opening temarks on the Digby glosses, Napier established that both Brussels and Digby have identical errors in a number of glosses. Eleven examples are cited, but I omit two as mistaken ${ }^{41}$ Forms in parentheses represent corrections which Napier supplied:

"The spacing may be coincidental, however, insofat as many Exeter manuscripts have widely separated lines, a characteristic of Eadwig Basan's innovative script; cf. Cambridge, Corpus Christi College 191 (Exeter, s. $x^{3 / 4}$ ). $\quad{ }_{32}^{32}$ Drage, 'Bishop Leofric', p. 372.

33 For the Brussels manuscript, Louis Goossens has discerned a number of hands which he terms 'A', 'B', 'C', 'CD' and ' $R$ '. I adopt Goossens's inventory, which is represented in my edition by superscript lower-case letters. Thus, $B^{\mathrm{C}}$ denotes scribe $\mathrm{C}$ in the Brussels manuscript. The reference numbers in each gloss citation refer to the number of the lemma in my edition: 13934, the final lemma glossed in any annotated copy of $P d y$, indicates the sequential number of that lemma in the list of lemmata. Reference numbers followed by a lower-ease letter are simply additions to the corpus, either discovered after the edition was complete or simply corrected.

34 The term 'group' went undefined in Napier's book. It seems to mean any manuscripts having a majority of their Old English giosses in common with one another. The evidence of shared

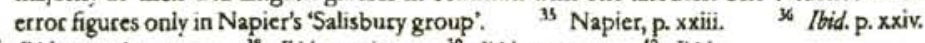

3. Ibid. pp. xxiv- xxv. 39 Ibid. p. xxiv. ${ }^{39}$ Ibid. p. xxv. ${ }^{2}$ Itid.

41 Glosses 4369 and 8975. Napier found most of these errors by collating Old English glosses in Royal 6. B. VII. 
The transmission of the 'Digby' glosses to Aldhelm's Prosa de virginitate

4637 SPIRITVS] orpas $B^{\text {cd }} \mathrm{O}$ (orpes, gen. sg)

5839 INEXPERTO) олсирит $\mathrm{B}^{\text {cd }} \mathrm{O}$ (илсирит)

7806 CVNICVLI] mepeles $\mathrm{B}^{\text {ed }}$ : orppeles $\mathrm{O}$ (orppelas, nom. pl.)

7959 NITEBANTVR] bi higde $\mathrm{B}^{\circ} \mathrm{O}$ (bigdon, pl.)

8696 DOLIVM] gpe $\mathrm{B}^{\mathrm{C}} \mathrm{O}($ grfe

10675 FACVLAS) sandberde brynas $B^{\text {cd }}$ : sandbarnde brynas $\mathrm{O}$ (sambarnde)

11787 THERMARVM] bapana $\mathrm{B}^{\mathrm{C}}$ : bapena $\mathrm{O}$ (bapa)

11827 RIPARVM] stap $/<e>n a \mathrm{~B}^{2}$ di: stapena $\mathrm{O}(\text { stapa })^{42}$

13351 ASSENTATRIX] gebwariende $\mathrm{B}^{\mathrm{C}} \mathrm{O}$ (geperariende)

On balance, only a handful of these glosses represent common errors which can be weighed as evidence of dissemination. ${ }^{43}$ Yet Napier concluded from these few correspondences that the Old English glosses in Brussels and Digby are 'very closely related'.4

The Old English glosses in Brussels and Digby were found to be linked, but Napier claimed that the Digby glosses could not have been the source of the Brussels corpus. In the first instance, he noted that Brussels often has 'better' readings than those in Digby, a circumstance which suggested to Napier that the Digby glosses could not have engendered the Brussels corpus. ${ }^{45}$ Napier gives thirty-one examples of this point, two of which are inaccurate. The remaining twenty-nine are cited below:

974 C.ARMINE] talsumum leope $\mathrm{B}^{2}$ : on gelsumum k'o'de $\mathrm{O}$

1405 IN COMPARATIONE] on wipmetenysse $\mathrm{B}^{\mathrm{ed}}$ : unurdmetenesse $\mathrm{O}$

1653 AMBRONIBVS] gifrum Ba": grifrum O

1781 AEMVLORVM] wipenvinnena $\mathrm{B}^{\text {cd }}$ : vipenvinna $\mathrm{O}$

2068 TRIBVNATVM] ealdordom $\mathrm{B}^{\text {ed: }}$ e ealdordomum $\mathrm{O}$

2134 E.PITAPHION] byriensang, 7 bergelsleod $\mathrm{B}^{c}$ : i sang $\mathrm{B}^{\text {ec }}$ : byriensang, leopsang $\mathrm{O}$

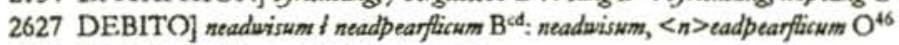

2705 CLAVSTRA] festenu $B^{\text {cd }}$ : fastenum $\mathrm{O}$

3395 L.APSVM] fornyrd t sllide $\mathrm{B}^{\text {ed: }}$ fonyyrd, stiden O

4692 DOCVMENTVM] bealic lar $\mathrm{B}^{\text {ed: }}$ : bealic lac $\mathrm{O}$

4978 VELAMENTO] under wafelse $\mathrm{B}^{\mathrm{cod}}$ : under mefesesse $\mathrm{O}$

2. Altered from stapa $\mathrm{B}$ :

- Some of Napicr's putative errors, in particular the grammatical ones, do not illuminatc the transmission. In 4637 the lemma SPIRITVS must be genitive singular (cf. Ehwald 258.4), although both Old English glosses are nominative or accusative plural. Similarly, the lemma CVNICVLI (7806) must be nominative (Ehwald 279.25), but it has been glossed as if it were genitive. These semantic errors might have originated with the earliest Pdo glossator, and they are not incontestably spurious. Gloss 7959 is bikewise an ambiguous indicator of dissemination, for unparallel bigde might have arisen in 2 manuscript reading NITEBATVR. Figde only appears as an error because of Digby's plural verb. More vahuable are 11787 and 11827 , although babasa for bapa and 11827 stepena for stapa could arguably represent morphological changes from strong to weak nouns. Such errors are not necessarily deviations, if morpholog. ical. ${ }^{41}$ Napier, p. xxiv. ${ }^{45}$ lbid. ${ }^{40}$ earlpearflirum $\mathrm{O}$. 
5359 RECIPROCIS] edlacendwm $\mathrm{B}^{\text {ed }}$; edladendwm $\mathrm{O}$

6546 PLANTA TENVS] op pa fohvelmes $\mathrm{B}^{\text {cd }}$ : op p a formylmas O

7014 FVRIBVNDVS] se gebatbeort $\mathrm{B}^{\text {cd }}$ : gebathord $\mathrm{O}$

7423 BOMBICINIS] gleenum, sidenkm B": goduebbenum Bed godenebbum, sidenum O

7524 CAPTIOSIS] 7 bedendlicum, of baftlicon $\mathrm{B}^{2}$ : of bafticon, bydenlicwm $\mathrm{O}$

7548 PALMAM] sigelean 1 edlean $\mathrm{B}^{\text {cd: }}$ sigelean, edlead $\mathrm{O}$

7642 SVRAS] sparliran Bc: sprerliran O

8285 AGGLOMERANTVR] wazran gegadrede $\mathrm{B}^{\text {ed. }}$, mazron gegarode $\mathrm{O}$

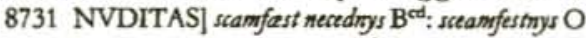

8973 INTEMPESTE] smelire $\mathrm{B}^{\text {ed }}$ : swyltre $\mathrm{O}$

9239 MASSAS] dyna $\mathrm{B}^{\mathrm{c}}$ : chyme $\mathrm{B}^{\mathrm{cc}}$ : crymas, clot $\mathrm{O}$

9488 LAVDABILI] of Lofficere $\mathrm{B}^{\text {ct. }}$ : of leoficere $\mathrm{O}$

10749 FONTIBVS] vilspringwm $\mathrm{B}^{\text {cd: }}$ aylsrin $\mathrm{O}$

10756 HORRISONO] egeslicum Bc: egeslico O

10870 RADERETVR] of assoren $\mathrm{B}^{\mathrm{c}}$ : on ascoren $\mathrm{O}$

12300 DECLINAVIT] be forbeab $\mathrm{B}^{\text {cd: }}$ be forbead $\mathrm{O}$

12871 LENOCINIA] forspen $\mathrm{B}^{\text {ed }}$ : sporspen O

13262 TALOTENVS] pa ancleo< $\left\langle>\mathrm{B}^{c}\right.$ : op pa ancneow $\mathrm{O}^{47}$

Unfortunately, Napier compromised his position at the start by failing to infer the textual transmission from shared error. Most of the 'errors' he identified involve the omission or misreading of one or two letters (e.g. 974, 1653, 2627, $2705,4692,4978,5359,7548,7642,8285,8973,9239,10870,12300$ and 13262 ), and such examples hardly constitute the kind of solid evidence which cditors rely on to group textual witnesses. For example, gloss 2705 has no editorial value. Any scribe writing fastenum could have omitted the nasal suspension when he saw that the lemma called for a neuter plural noun. A copyist could likewise have added the abbreviation to fastenum out of carelessness. Sound changes, too, could account for 4978 (ls>ss) and 7524 (ndl>nl), just as morphological slips might explain 1781 and 2068. Ultimately, Napier ought to have questioned his rigid adherence to 'correct' spellings of Old English as evidence of dissemination. Almost all of the examples he provided to illustrate his position are equivocal.

In the same vein, Napier supplied ambiguous citations to illustrate a second, equally indefensible, position. Napier contended that 'the still more numerous cases in which [Digby 146] has a better reading than [Brussels 1650] shows that the latter is not the original of [Digby 146] ${ }^{3}{ }^{48}$ He lists twenty examples and states that they are 'almost unnecessary' to prove his point:49

47 altered from $f \mathrm{~B}^{c}$. $\quad{ }^{43}$ Napier, p. xxiv.

4 Because he relied on Bouterwek's edition of the Brussels glosses (C. Bouterwek, 'Angeisächsische Glossen (1): die ags. Glossen in dem Brüsseler Codex von Aldhelms Schrift De Virginitate', Zeitsclorift für destsches Alterthwm 9 (1853), 401-530), Napier's examples corresponding to 3014 and 4065 are no longer valid. Gloss 1169 has been shifted from the section dealing with better readings in $\mathrm{B}$ against those in $\mathrm{O}$; it is erroneously included there. 
The transmission of the 'Digby' glosses to Aldhelm's Prosa de virginitate

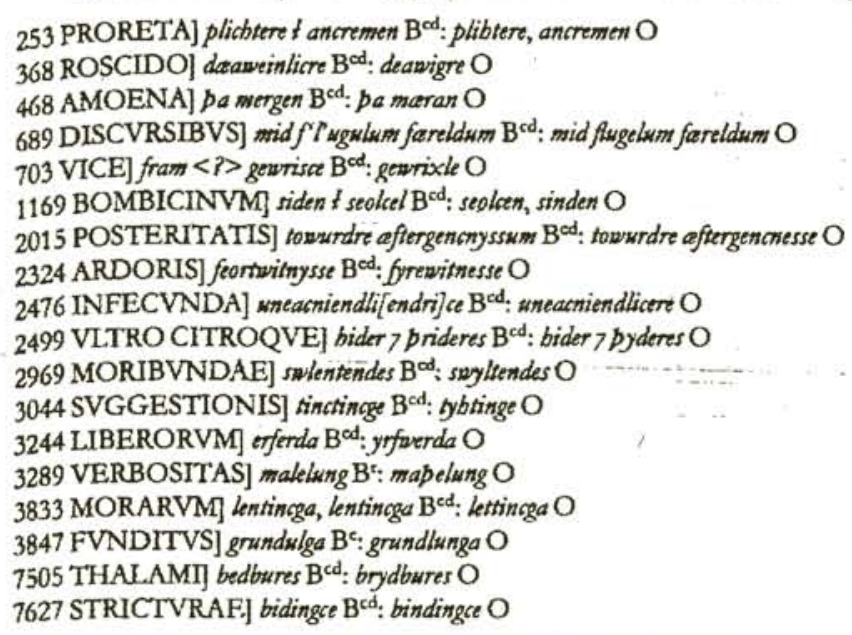

Some of Napier's glosses simply exhibit orthographical variance: 253 (plichtere/plibtere), 689 (f'/ ugulum/flugeium), 3244 (erferda/yrfwerda). Furthermore, both glosses to 7505 are legitimate nominal compounds, and neither can claim precedence. In cataloguing the preceding variants, then, Napier did not consider that a spelling - or word - in either manuscript could be due to scribal corruption or correction. For some glosses Brussels preserves a better reading. That fact might mean that the Digby copyist was sometimes careless, accidentally adding a nasal suspension (2705) or miscopying an $r$ (4692). More often, the Digby manuscript gives a better reading, arguably implying that the Digby scribe was correcting mistakes he came upon in the exemplar. In this respect, would it be hard for a native speaker of Old English to perceive the proper words in such corruptions as genrisce (genrixl 703), seolcel (seolcen 1169), feortwitnysse (fyrewitnysse 2324), and uneacniendliendrice (uneacniendlice 2476) $?^{50} \mathrm{Ker}$ and Goossens showed how the process of correction and corruption worked when they examined certain errors arising in Digby 146.

Given that they were based on so brief an analysis, Napier's generalizations were unjustifiable. The simple fact that the Digby glosses were written primarily in a single hand and the Brussels glosses in five hands or more should have prompted Napier to review his argument. He relied, however, on Bouterwek's edition of 1853 of the Brussels glosses, which does not discuss the palaeography of the manuscript. Hence, Napier confidently reckoned that the Old English glosses in both Brussels and Digby descend from the same source,

31) Similarly in $2499,2969,3847$ and 7627 . 


\section{Scott Gwara}

which he later called ' $Y$ '. The fanciful transmission that Napier alleged for the compilation of this ' $\mathrm{Y}$ ' archetype (p. xxv) reflects his biased evidence.

Ultimately, Napier's investigation boasts a more pernicious shortcoming than its fruitless comparisons: his classification rests solely on the Old English glosses preserved in the Pdv manuscripts familiar to him. Thousands of Latin glosses were neglected, presumably because Napier could not find any common link between the Old English and Latin contributions in the manuscripts he studied. The Latin glosses, it turns out, are essential to understanding the gloss transmis. sion and cannot be overlooked.

Louis Goossens legitimized Napier's methodology in 1974, although he made significant modifications to Napier's fictitious stemma. In particular, he dismantled Napiet's transmission of the 'Digby' family and even rejected the term 'Digby group'. Goossens preferred 'Abingdon group', and his reasons stem from the transmission which he proposed. For example, Goossens refined Ker's proposal that the Old English glosses in Digby 146 were copied directly from Brussels 1650.51 Napier's hypothetical ' $\mathrm{X}$ ' and ' $\mathrm{Y}$ ' archetypes were illusory, Goossens implied, and the phrase 'Digby group' a misnomer. ${ }^{52}$ Nowadays, one gloss family is incongruously named after a manuscript, the other after a conjectural provenance.

Goossens had considerably more to say than Napier about Royal 6. B. VII. He argued that glosses in Royal 6. B. VII descended directly from Brussels 1650, rather than from Napier's lost manuscript ' $X$ '. ${ }^{\text {s7 }}$ He has reaffirmed this claim in a recent article. ${ }^{54}$ Yet Goossens's ingenious hypothesis fails to account for all the Old English Royal glosses, as well as for thousands of Latin ones. For this reason alone, his theory invites criticism. ${ }^{55}$

Unfortunately, Napier's and Goossens's classifications inadequately describe the relationship of Old English and Latin glosses in Pdv manuscripts. Neither scholar credits the value of Latin glosses, which bear significantly on the dissemination. Goossens alone discusses the various scribal hands, which record the growth of the gloss corpus, but he does so for one manuscript only. In the following pages, then, I offer a reassessment of the dissemination of this

5i See below, p. 151 .

52 Napier's "Digby group" may suggest that [Digby 146$]$ is the central member of the group, which is not the case. "Abingdon group" is a better term because both [Brussels 1650] and [Digby 146] are Abingdon MSS., whereas [Royal 6. B. VII] and [Hereford P. I.17] are closely connected with them" (p. 22). 53 Ibid. pp. 23-5.

s4 "Latin and Old English Aldhelm Glosses: a Direct Link in the "Abingdon Group" "Angla facon Glossograpby, ed. R. Derolez. (Brussels, 1992), pp. 141-9.

ss Ibid. p. 27. Goossens had earlier qualified his own prodigious efforts: 'In neariy all cases it will be impossible to cstablish direct relationships among the Oid English glosses: it is good to remcmber in this respect that for each [manuscript] which has come down to us several others must have been lost in the course of time' (p. 21). 
The transmission of the 'Digby' glosses to:Aldbelm's Prosa de virginitate

important corpus of glosses. In my discussion, I refer periodically to the 'Digby' or 'Abingdon' groups. By retaining the nomenclature, I try to show where Napier's and Goossens's categories remain viable. For all intents and purposes, however, the distinctions are both impressionistic and casual.

THE RELATIONSHIP OF OLD ENGLISH GLOSSES IN BRUSSELS HAND

CD TO GLOSSES IN THE 'ORDINARY HAND' OF DIGBY 146

Any serious study of the Digby' glosses to $P d v$ must begin with the Brussels (B) and Digby $(O)$ manuscripts. The codices contain, by far, the largest number of Old English Aldhelm glosses, and they are surpassed only by Royal 7. D. XXIV in the number of Latin ones. The relationship of Old English glosses in B and $\mathrm{O}$ is complex, but $\mathrm{Ker}$ and Goossens left a roadmap to the transmission of certain gloss strata. Their analyses suggest persuasively that the bulk of Old English glosses in Digby 146 was copied directly from Brussels 1650.

Writing in 1955 René Derolez pointed out that the Old English Digby glosses represent a copy of those in Brussels $1650,{ }^{56}$ and Ker advanced Derolez's position, apparently independently, two years later:

... there does not seem to be any serious objection to the theory which Napier rejected, that the Digby glosses were copied from [Brussels 1650], if we may assurne that the copyist tried to correct mistakes in his exempiar and to alter some of the dialectal forms. Some of the forms can best be explained as errors in copying from [Brussels 1650], e.g. in gl. 26 'torhtte' [ $=245$ ], the spelling $"$ may be due to the aiteration in [Brussels 1650] of 'torhta[.]' (originally 'torhtas'?) to 'torht $x$ ', the second $t$ and flat-topped $x$ following it resembling tte. The reading 'horrescunt' in [Brussels 1650] ${ }^{57}$ has given rise to the gloss 'andprac[h]iap' in both manuscripts (gl. 3185) [ $=7476]$, although Digby has correctly "herescunt.'.

Goossens accepted Ker's reasoning. He suggested that the systematic method of copying confirms that Brussels 1650 was the direct source for most of the Old English glosses in Digby 146. In fact, almost every Old English gloss in Brussels is accounted for in Digby. Even Goossens's 'exceptions' support his hypothesis, for he mistakenly assumed that 'there is no counterpart in $\mathrm{O}$ for $\mathrm{B}$ $1-78,80-86,88-96$ and $98 .{ }^{\prime 59}$ These glosses have been erased in O. Few glosses were therefore omitted from the corpus, in Goossens's words, 'only the duplications, some of the marginal gll by hand 3 in B, and the last $O E$ gl. in B, which is no gl. to the text'. ${ }^{60}$ This kind of manuscript collation, arguably intended to bring both manuscripts into conformity, is reflected in other glossed Pdv copies.

Following Ker's approach, Goossens identified five other erroneous glosses in Digby 146 which can be traced to a misteading of Brussels entries:

* Cf. 'De oudengelse Aldhelmglossen'. 57 "Only B has this variant. $\quad 58$ Ker, pp. 382-3.

${ }^{39}$ Goossens, p. $26 .{ }^{60}$ lbid. 


\section{Scott Gwara}

1851 BELLICOSAS] wigdic/'b'ear<d>lice $\mathrm{B}^{\text {csdi }}$, vibearde $\mathrm{O}$

The gloss was altered from viglice, ' $h$ ' and 'ardlice' were added by $C D$, and ' $d$ ' was altered from $\%$. This badly executed correction gives rise to wibearde in $\mathrm{O}$, whereas two glosses in B were intended: siglice and beardlice.

2134 EPITAPHION] byriensang, 7 bergelslead $\mathrm{B}^{\mathrm{c}}$ : / sang $\mathrm{B}^{\mathrm{d}}$ : byriensang, kopsang $\mathrm{O}$

In the Brussels manuscript the gloss bicleod is emended to bicsang, with 'sang' written above ' $\delta$ ' in ticleos. This has produced the erroneous kopsang in $\mathrm{O}$.

2053 TEXTRINVM] web/lic gewwre Berd: weblic, geweorclic $\mathrm{O}$

In B genwre is written above seblic and engenders the nonce-word geweorlic in O.

2535 BIS TINCTOI mybiu<um> Bc: tnybivadum O

The gloss in B has been corrected from taybive by erasure and substitution of ' $u$ ' with nasal suspension. In Goossens's view, confusion accounts for the gloss trybinadum in $\mathrm{O}$.

\section{PROCVMBERE] b' $n$ 'phte $\mathrm{B}^{\text {ed: }}$ : brimpte O}

Goossens explains that the Brussels gloss is situated just beiow the lemma CORRVERET, in which the first $r$ is 2-shaped and consequently has a horizontal bottom stroke looking like a long mark of abbreviation over ' $b^{\prime} n n^{\prime}$ 'pte'. ${ }^{61}$

This additional evidence strongly supports the argument that Digby was collated against Brussels. Obviously, there may have been an intermediary exemplar, but none is demonstrablc through an examination of the glosses. I therefore concur with Ker and Goossens: the meticulous method of transcription suggests that the Old English glosses were copied directly from Brussels into Digby.

The Brussels $C D$ glosses form a vast corpus attesting to the intensive study of Pdv. As a corpus, however, the glosses have few parallels, apart from scratched glosses preserved in three manuscripts with connections to Canterbury. Until these scratched glosses are fully edited and profitably compared to those in the Brussels corpus, neither the origin nor the dissemination of the 5,500 Old English glosses in Brussels 1650 will be known. Simply speaking, no substantial comparable $P d v$ glosses exist prior to the date of the $\mathrm{CD}$ scribe. Hence, the $\mathrm{CD}$ corpus, ostensibly copied from an exemplar, has no extant source.

THE RELATIONSHIP OF GLOSSES IN BRUSSELS HAND C (FIRST

$$
\text { STRATUM) AND ROYAL 6. B. VII (MAIN STRATUM) }
$$

The Old English and Latin glosses written by the five identifiable Brussels scribes and by the 'Ordinary Hand' of Digby 146 represent a significant portion of glosses in these manuscripts. Thus far, however, only the 'Ordinary Hand' glosses in Digby and the CD glosses in Brussels can be accounted for in 
The transmission of the 'Digby' glosses to Aldhelm's Prosa de virginitate

terms of their textual history. Glosses in the Digby 'Ordinary Hand' derive from Brussels, but what is the source of the Brussels hands other than those by $C D$ ? For the present, I shall set aside glosses in HANDS A and B, and examine the glosses in HAND C. These, we may recall, are in two separate layers. The first layer comprises interlinear Old English and Latin glosses. The second layer comprises marginal glosses in Latin (mainly on $8 \mathrm{r}$ and $9 \mathrm{v}-11 \mathrm{r}$ ) ${ }^{62}$ and the series of glossae collectae which turn up in the margins from $19 \mathrm{r}-53 \mathrm{v}$. These different layers imply that the glosses in HAND C may have had two discrete sources, and the evidence of collation suggests the same. Before setting out this evidence, however, my position can helpfully be formulated in advance.

First, apart from the glossat collectae, the marginal scholia in the second layer of Brussels scribe $C$ appear to derive from a source from which the Digby marginalia also descend. A collation of the common glosses implics this relationship without making it certain. Secondly, the interlinear glosses in the first stratum of HAND C must have come from Digby 146, for HAND C of Brussels 1650 incorporates errors which can be traced unequivocally to the Digby manuscript. Some of these same errors, as well as comparable ones, appear in Royal 6. B. VII. The nature of the errors common to Brussels HAND C (first layer) and Royal 6. B. VII (main glossing hand) proves that an antecedent manuscript was the source for both of them.

In his book Goossens surmised that 'with comparatively few exceptions, the gll. of [Royal 6. B. VII] were copied from those in [Brussels 1650] at a stage when the glossing there had not yet been completed'. ${ }^{3}$ He repeats this very hypothesis with the same wording in his article of 1992. From the outset, however, the hypothesis is unfeasible, since all the Brussels glosses had been added by $5 . \mathrm{xi}^{\mathrm{med}}$, and the Royal manuscript postdates these accretions. ${ }^{64}$ To salvage Goossens's argument, one would have to postulate an intermediary exemplar which was copied from Brussels at the stage Goossens alleges and which came into possession of the Exeter community in time for the Royal copy to be made. Because establishing an intermediary superficially appears to resolve several problems, let us assume that such an intermediary existed and proceed to Goossens's evidence.

22 Goossens (p. 48) claimed that these do not pertain to the text. In fact, the lemmas to these legitimate glosses appear throughout. $\quad$ ss Goossens, p. 23.

64 Goossens nowhere cites Drage's work, and the dates of the gloss-hands in the manuscripts (cf. Goossens, p. 17) rest on ourdated descriptions. Moreover, his argument calls for justification on grounds of provenance. If glosses from Brussels 1650 were copied into Royal 6. B. VII, either Brussels 1650 must have been at Exeter or the Royal seribe must have travelled to the foundation housing the Brussels volume, either Canterbury or Abingdon. Neither hypothesis can be verified from known evidence. 


\section{Scott Gwara}

Goossens made a series of arguments in favour of his thesis that the glosses in R5 descend directly from those in B. ${ }^{65}$ Primarily, he asserted that 489 Old English glosses in R5 - a substantial majority - agree with those in B. 356 of these glosses occur in HAND C, about 109 in HAND A and 24 in HAND B.6s By contrast, only twenty-nine CD glosses appear in R5, ${ }^{67}$ and none in HAND $R$ (in red ink). How, Goossens asked, could a corpus of glosses represented by three hands in one manuscript appear as one hand in another volume, if the glosses in the later manuscript were not copied from the earlier? Goossens had concluded in his edition, if the glossator of R5 did not copy from B, he must have drawn his material from the same sources (or sources very similar to) those of the first, second and third hands in B, which is not very likely'. ${ }^{69}$

Goossens subsequently broadened his base of evidence and further refined his analysis. He maintained that there are even greater correspondences between the Latin glosses in R5 than between the Old English glosses: 'Our strongest argument comes from the Latin glosses in MS. R5. They agree for about $95 \%$ with glosses in MS. B and with few exceptions are identical with them. ${ }^{10}$ Having made this statement, Goossens recognizes a problem: as many as forty-four Old English glosses in Royal 6. B. VII are not present in Brussels." Goossens endeavours to dismiss these glosses, but nine of them can only be explained as having arisen from another source. ${ }^{72}$ Goossens would have been rewarded by examining the Latin glosses at this stage of his argument. Dozens of them, too, are not in $\mathrm{B}:{ }^{3}$

1141 DEFORMATVR] i. non deformatur R5: i. non deturpatur $O$

1252 PVTANTVR] i. estimamus uel putamur R5: i. estimamus $O$

1353 CVM CONSTET] i. certum est $R 5$ : i. testum est $O$

1615 DINOSCITVR] s. illa superbia, arrogantia R5: s. illa superbia O

1951 RECESSIBVS] i. occultationibus, $i$, visceribus $R 5$ : $i$. uisceribus $O$

2160 APOSTOLICAE] i. episcopalis R5

2409 PLENE] i. omnino, aduerbialiter R5: i. omnino O

2944 FACTIOSAM] i. fraudulentiam R5: $i$. falsam O

is Goossens, pp. 23-4; idem, 'Aldhelm Glosses', p. 142.

* Goossens, 'Aldheim Glosses', p. 142 Ez Ibid. p. 143. "s Ibid.p. 144. "Ibid. p. 23.

10 Cf. Goossens, p. 24: The agrcement berween [Royal 6. B. VII] and [Brussels 1650] is much greater here than for the Old English glosses, especially as regards the number of gll. that were taken over. On folio SR e.g., the glossator of Royal 6. B. VII took over only one OE gh. against 70 Latin gll., on folio $6 \mathrm{R}$ no less than 87 Latin gll., but not a single OE gl.'; cf. Goossens, 'Aldhelm Glosses', p. 142. $\quad n$ Goossens, 'Aldhelm Glosses', p. 147. $\quad 12$ Ibid. p. 148.

3 Not to mention: $3927,3984,4005,4333,4700,4715,4763,4792,4952,5224,5351,5409,5554$, $5590,5616,5734,5957,5991,5993,6032,6073,6099,6507,6594,6668,6863,6926,6990$, $7403,7411,7525,7577,7683,7738,7908,8070,8402,8458,8495,8578,8663,8824,9067$. $9277,9368,9807,9841,9939,9987,10251,10289,10480,10681,10811,10852,10921,11044$, $11816,12084,13564,13575$ and 13808 . 
The transmission of the 'Digby' glosses to Aldhelm's Prosa de virginitate

3052 DEDIT] i. locupletati R5: $\mathrm{i}$. subiecti O

3397 CAEREMONLAS] i. obseruationes R5

3478 SVPREMAM] i. ultimam $R 5$

3592 SVB CONO] i. summa parte R5: sublimis summus grandis excelsus preclarus $\mathrm{O}$

3597 PRAEPETH] i. ueloci R5: i. celeri $Q$

3724 CENSVRAM] i. estimationem uel mensuram R5: $i$ i iudicium $O$

3878 CONGESSIMVS] i. collegimus R5: i. congregauimus $O$

3892 PROCERTTAS] i. celsitudo uel altitudo RS: i. magnitudo uel status, longitudo $\mathrm{O}$

3914 CREDATVR] s. qui, mercatur R5

No doubt Goossens would have conjectured that these glosses stem from his source and that they would have been added in the transitional stage we have allowed for.

Superficially, Goossens's argument seems fine. Certainly, the intimate relationship between glosses in $\mathrm{R} 5$ and $\mathrm{B}^{\mathrm{c}}$ is beyond doubt. In fact, if Goossens had printed all the Latin entries in the Brussels codex and compared them to those in Royal 6. B. VII, he would have noted examples of shared error in R.5 and Bc which buttress his case:

1886 INFLEXIBILE] innodabile R5 Bc; inenodabile Ó

3463 VERBORVM] seruorum R5 $\mathrm{B}^{c}:^{74}$ sermonum O

3774 FLAMMIVOMA] a flamma et umbo $R 5 B^{c}$ : a flamma et uerbo $O$

4161 SOFISTAE] sophistica facta $R 5 B^{c}$ : sofistica ficta $O$

4389 PROCACIBVS] inprudentibus $\mathrm{R}^{5} \mathrm{~B}^{\mathrm{c}}$ : inpudentibus $\mathrm{O}$

4541 PROPALAT] presens pro pretereo R5: presens pro preterio $B^{c}$ : presens pro pre-

terito $O$

4646 LATEBRARVM] sacratorum R5 Bc: secretorum O

4910 SEMITAM] uitam $R 5 B^{4}$ : uiam $O$

5012 EVENTVM] quod deuenit R5 Bc: quod euenit $O$

5032 GLORIA] honora R5 Bc: honore O

6431 OBLIQVO| turto vel curuo R5: curto uel curuo Bc7s

Obviously, there is a material connection between the glosses in HAND C of Brussels and the glosses in Royal 6. B. VII. Alas, it never struck Goossens that an equally close connection exists between glosses in Royal and Digby, manuscripts which are about 100 years apart in date. After discerning that the Old English glosses in Digby had been copied from B, Goossens neglected to collate the Latin Digby glosses with those in R5 and B. In fact, hundreds of Latin glosses are unique to these three manuscripts. Furthermore, Goossens overlooked errors common to $\mathrm{R} 5 \mathrm{~B}^{\mathrm{c}}$ and $\mathrm{O}$, such as $183 \mathrm{PANDO}$ ] curruu $\mathrm{R} 5 \mathrm{~B}^{\mathrm{c}} \mathrm{O},{ }^{76} \mathrm{He}$ also

7 Corrected to sermonum B. 75 For torto nel carmo. 76 Altered to carvo Bc. 


\section{Scott Gwara}

neglected errors common to $O$ and $R 5$ alone, such as 5392 PERTTORVM] predentium R5 O (for prudentium, omitted in B). Several errors common to Royal 6. B. VII and Digby 146 stand corrected in B as well:

4381 QVAESTVVM] lucrarum R5 O: lucrorum $B^{c}$

5479 MARTIRIZARETVR] cruaretur R5 O: cruciaretur Bc 6806 VICTORIA] tropheti R5 O: $:^{77}$ trophea $B^{\text {c78 }}$

These variants prove that the glosses in Royal 6. B. VII must be related to those in Digby 146 as well as to those in Brussels 1650. Could the Latin glosses in Digby, like the Old English ones, have also come from Brussels? The dating of the gloss hands makes this impossible. In fact, a closer look at more substantive errors demonstrates beyond any doubt that an intermediary copy of certain Digby glosses must be the source of glosses in the first stratum of Brussels HAND C and the main stratum of Royal 6. B. VII. I call this Digby apograph *O.

In the following erroneous glosses, distinguishing features in the layout and script of the Digby manuscript account for glosses in Brussels and Royal. Threc kinds of error characterize the Digby apograph which gave rise to the glosses in these manuscripts. In several places a copyist of Digby truncated a gloss, leading to an ungrammatical transcript. He also took marginal material spreading into the line as part of an interlinear annotation; the resulting glosses are often nonsensical. Finally, he mistakenly copied sections of long interlinear glosses, so that the last portions of them, often a word or two, appear over adjacent lemmas. By reference to these varieties of error arising in an apograph of $\mathrm{O}$, we can interpret seemingly inexplicable glosses in $\mathrm{R} 5$ and $\mathrm{B}$ :

2130 L.AMENTABILE] lamentabile flebile luctuosum funes R5: flebile luctuosum B:

Lamentabile fiebile luctuosum funesturn plorabile lacrimabile $\mathrm{O}$

2132 QVOD] funes $B^{c}$

In the Digby copy of $P d v$ the gloss to LAMENTABILE reads (19v1):

lamentabile fiebile luctuosum funes tum plorabile lacrimabile

The first line ends at funes, and a scribe has only copied to this point, thereby omitting -tum. The erroneous gloss appears in B (9r3), except that fwres is taken as a gloss for the later lemma QVOD. The same error occurs in R5 $(11 \mathrm{r} 20)$. Note that fwnes, which makes no sense, might have been mistaken for fwnks.

2175 RADICIBVS] radices dicuntur R5 B5: Radices dicuntur que in imo atque in occulto site sunt $\mathrm{O}$

$n$ tropbeti altered to trophea $\mathrm{O}$.

76 And possibly 6439 SVSPICIONVM] iudiciarum R5: iudiciorum B $c_{4}$ indiciarum O. 
The transmission of the 'Digby' glosses to Aldhelm's Prosa de virginitate

The marginal gloss in $\mathrm{O}(19 \mathrm{v} 11)$ reads as follows:

Radices dicuntur que in imo atque in occulto site sunt

The scribe of the Digby apograph only bothered to copy out the first line of the gloss before realizing he had no space to complete it. His brief transcript is taken over in Brussels (9r10) and Royal (11ष3).

2180 SPISSA] i. spissum densum, i. in unum collectum R5 O: densa, in unum collecta B $O$ reads densum (19v13), with the interlinear gioss in unum collectum directly above the following lemma VIRGVITORVM. This format has confused a copyist, who took the second part as a gloss to VIRGVLTORVM. In R5 (11v4) and B (9r10) this same arrangement is duplicated.

2260 VVLNVS] i. aporia, cura, $i$ angor $\mathrm{R} 5 \mathrm{~B}^{\mathrm{C}} \mathrm{O}$

The word angor appears above the following lemmas IN MENTE in the Digby manuscript (20r13). It is treated as a separate gloss to that term boch in R5 (11v19) and B (9v4).

3389 VOCIS] i. uox dicitur R5: uox dicitur quicquid sonat $\mathrm{O}$

3390 MVGITVM] i. quicquid sonat R5 $\mathrm{B}^{\mathrm{c}}$

In manuscript $O(27 \mathrm{r} 14)$ the gloss to VOCIS reads as edited above, but the final words quicquid sonal are written above the following lemma MVGITVM. These words have been taken as a gloss to this lemma and are written separately with $i$ in R5 $(16 \mathrm{r} 9-10)$. The first, nonsensical, half of the gloss is omitted in B (14r1).

3442 TENERITVDINE] i. tenerum molle fragile, i. flexum flexibile R5: i. tenerum fragile molle flexum flexibile $B^{c}$ : i. tenerum fragile molle flexum flexibile $O$

In $\mathrm{O}(27 \mathrm{v} 6)$ the long interlinear gloss runs across the line, and the words feexum flexibile occur just above the following lemma VIRGINITATI. In B $\left(14 \mathrm{r}^{9}-10\right)$ a similar arrangement crops up, but the words have been shifted to suggest that they gloss VIRGINITATI. In R5 (16r18-19) they were separated from the first part of the gloss and taken as an interpretation of VIRGINITATI as well.

3569 MINVTATIM] i. gradatim, i. ordinatim R5: i. gradatim, ordinatim Bc: i. gradatim uel ordinatim $\mathrm{O}$

In $\mathrm{O}(28 \mathrm{r} 16)$ there is no Latin gloss to the preceding lemma ABSCISO. Gradatim was taken as a gloss to this word and became misplaced in the Digby apograph. The misplacement shows up in R5 (16v18) and B $(14 \mathrm{v} 10)$, and the single gloss ordinatim was written above MINVTATIM in both manuscripts.

6878 FERRO FORTIOR] i. semina frugum R5 Bc: Ferrum dictum .... O

The long marginal gloss in O (48r11), which comes from Isidore, Etym. XVI.xxi.1, reads as follows: 


\section{Scott Gwara}

Ferrum dictum quod farra i. semina frugum

terre condeat idem et calips

a calibes flumine

ubi ferrum optima acie temperatur

unde et abusiue dicitur calips

ipsa materies

The words semina frugem appear directly above the lemma FERRO FORTIOR, since the gloss runs into the text. The gloss was then truncated in an apograph, and the error appears in R5 (28v5) and B (27r16).

8042 POLLVENDO] comminando R5 Bc: contaminando $\mathrm{O}$

The gloss in $\mathrm{O}(55 \mathrm{v} 14)$ is correct. Yet the ascenders in POLLVENDO divide the word at contamin//ando. A corruption arose in this way, and the error appears as comminando with various marks of abbreviation in R5 (32v1) and B (31v22).

These entries are conclusive evidence that the glosses common to $\mathrm{B}^{\mathrm{c}}$ (first layer) and R5 stem from a manuscript copied from $O$. No reasonable alternative explanation accounts for the errors discussed above as well as for other errors common only to Digby and Royal, to Digby and Brussels, and to Digby, Brussels and Royal together. Yet a common exemplar not only explains the unusual, irreproducible errors appearing identically in Royal 6. B. VII and Brussels 1650. More conveniently, it accounts for errors unique to glosses in each of these codices.

In my view, this hypothetical copy of $\mathrm{O}(=* \mathrm{O})$ must have had even more corruptions similar to the ones just described but not introduced into R5 or B, either because the error was corrected or because the gloss was ncver copied. Glosses 3389-90, cited above, illustrate my reasoning. At this point in Pdv Digby 146 contained a relatively long interlincar gloss which became divided in my alleged transcript. The division is fortuitously recorded in R5, but the Brussels codex has only half of the gloss: 'quicquid sonat'. A scribe, possibly scribe $C$, eliminated the useless gloss 'uox dicitur' here. This scribe, or the scribes of any intervening archetypes, may have made similar emendations to correct faulty readings arising from Digby. Other (admittedly problematic) examples in the Brusscls corpus are:

8075 CYCLADIBVS] i. uirginilibus uestibus R5: uirginalibus Bc: uirginalibus uestibus $\mathrm{O}$ Apart from the minor error srirginilibus, the glosses in R5 (32v6) and $O(56 \mathrm{r} 3)$ arc identical. The gloss in B, however, makes no sense (32r6). Looking at $\mathrm{O}$, we can see one way this gloss may have arisen: the final term westibus extends into the margin and may have been taken as a gloss to the following lemma. If the Digby apograph preserved this format, the Brussels scribe might mistakenly have omitted the final term. The scribe of R5 may have noticed the misplacement and put matters right.

8722 GVRGITIS] i. fluminis, proprie latus altus in flumine R5: fluminis, est proprie latus $B^{c}$ : i. fluminis, Gurges est proprie lacus altus in flumine $O$ 
In Digby 146 the final wotds in fumine are written over the following lemma (60r5). They may have been mistakenly attached to it in the apograph and re-located correctly only in R5 (32v6). Note that the Insular $\mathrm{c}$ has given rise to the common error latus in R5 and $B^{c}$ (34v5).

Comparable scribal confusions which appear in $\mathrm{R} 5$ are more obviously attributable to a Digby apograph. We have seen, for example, that long interlinear glosses were often truncated and the various parts reassigned to preceding or following lemmas. Many more examples of this phenomenon are documented in the Royal copy of $P d v$, and they attest to a more corrupt transcript of Digby 146 than the Brussels text does. In other cases an unnoticed abbreviation engenders a serious mistake.

952 VERTICEM] cacum R5: cacumen $\mathrm{B}^{\mathrm{C}} \mathrm{O}$

The nasal suspension above the ' $m$ ' in $O(12 v 3)$ is placed high, and the word runs directly into the glossword for the following lemma. A scribe seems to have been missed the abbreviation, giving rise to the meaningless cacum in R5 (6r16). The Brussels scribe recognized the mistake in his exemplar (4v14).

1562 ROSCIDIS] i. humidis, i. rore madidis R5 $\mathrm{B}^{\mathrm{c} O}$

In Digby (16r7) as in Brussels (6v22) this entire gloss is placed interlinearly, and it runs over the following lemma OCVLORVM. In R5 $(8 \mathrm{r} 18)$ the sccond half rore madidis appears as a separate gloss to OCVLORVM with the abbreviation $i$.

2011 PATERNAE] s. terram repromissionis $\mathrm{R}^{2} \mathrm{~B}^{\mathrm{C}} \mathrm{O}$

In Digby (18v9) and Brussels (8v4) this long gioss extends over the following lemma GENERATIONIS. In R5 it is separated (8r18), the first half terram glossing PATERNAE, the second half repromissionis glossing GENERATTONIS.

2529 TTNCTVRAEl tinctus luridus infectus coloratus R5 B $\mathrm{O}$

This long interlinear gloss covers several words in Digby (21v19) and Brussels (10v5). The final term entoratus appears over the verb SPLENDVISSE. While all the glosses are correctly placed in Brussels, in the Royal manuscript (12v19-20) i. coloratus occurs separately above SPLENDVISSE.

4050 PATENTE] i. aperiente, i. manifestante $\mathrm{R}^{5} \mathrm{~B}^{\mathrm{C}} \mathrm{O}$

In Digby (31r1) and Brussels (16r22), these interlinear glosses extend beyond the lemma, and manifeslante is written over the following lemma VOCE. Manifestante appears as a separate gloss to VOCE in R5 (18v1).

5060 BIGARVM] bige ubi duo i. curru iunguntur R5: curruum B': i. bige ubi duo equi curru iunguntur $\mathrm{O}$

In Digby 146 the interlinear gloss to BIGARVM runs over a large part of the line (36v12). The words curnw ikngwntur appear above SVBIVGALES. While HAND C in B writes simply cwrrum as a gioss (20r19), a reflex of the layout in O appears in R5 (22r9): curru iunguntur is a separate gloss to SVBIVGALES, and equi, which in O straddles the lemmas BIGARVM SVBIVGALES, is missing. The gloss makes no sense, perhaps explaining why it was omitted in B. 
8442 STOLIDA] i. rori stulta R5: stulte Bc: stulta O

The interlinear gioss to STOLIDA in $\mathrm{O}(58 \mathrm{r} 16)$ is straightforward, but a marginal gloss to the preceding lemma GINGINIS gives rise to an error in the hypothetical apograph:

\author{
Gingiue a gignendis \\ dentibus nominatae \\ facte sunt \\ etiam ad dec \\ orem dentium hor rori \\ potius quam orna \\ mento existerent
}

The word horrori in this gloss has been divided in two by the capital 'S' of SIC, just preceding STOLIDA. The glossator therefore took rorias part of the gloss and wrote reri stulta in his apograph. This appears in R5 (33v15). The Brussels scribe probably recognized that rorimade no sense in the context ('foolish to dew'l) and omitted it from his text (33v3).

Although these etrors occur only in R5, their obvious affinities with the variecies of error common to R5 and $B^{c}$ imply that they were in the Digby apograph that gave rise to the Brussels HAND C glosses. Omissions of such mistakes in either manuscript are attributable to the vigilance of scribes, who corrected or omitted these problematic entries.

Because layers of glossing in Digby 146 can be dated palaeographically, the Digby apograph was indisputably penned after the glosses by Ker's scribe (i) (=Napier's 'second Latin hand') and Napier's 'Ordinary hand' but before the Old English glosses by Ker's scribe (ii) (=Napier's 'Second hand'), that is 6 $980 \times 1020$. The evidence derives from collation. Glosses in Ker's hand (ii) appear neither in Brussels HAND C nor in the main hand of Royal 6. B. VII, whereas glosses in hand (i) and in Napier's 'Otdinary hand' crop up consistently. Incidentally, because Digby 146 preserved about thirty Old English glosses in its earliest stratum and because these glosses were copied into the Digby apograph, some redundant glossing arose in Digby when the vernacular glosses were transferred from Brussels 1650 .

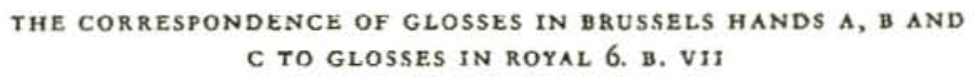

Goossens wrongly derived glosses in R5 from those in B, and his reasoning needs to be considered in more detail. He contended that glosses in three hands which elsewhere correspond closely to glosses in one hand must have given rise to them. His evidence is, as outlined above, 109 glosses in HAND A, 24 glosses in HAND B and 356 glosses in HAND C which are common to glosses in R5. In the following instances I provide some of his uncited 
The transmission of the 'Digby' glosses to Aldhelm's Prosa de virginitate

examples, Old English glosses found in Royal 6. B. VII which agree with those in Brussels HAND A: ${ }^{79}$

255 NAVCLERV] rowendes $\mathrm{R} 5$ : novend $\mathrm{B}$ *30

1192 DACTHLOS] ctistro R5: chstra, fingerappla B*

1335 CAVLICVLVS] stela R5 B

1719 GENVINIS] fơేreamum $\mathrm{R} 5$ : $00\langle p\rangle$ reomkm $\mathrm{B}^{281}$

2510 FVCOI dage R5: deage $\mathrm{B}^{a}$

2684 PASTINARE] byddrian R5: tidrian B*

2830 TORTIS] apranenum R5: gepravenum B*

2847 CAESARIE] foc RS B*

2857 INDRVTICANS] tigende R5 B*

2909 CONDICIO] raden $\mathrm{R} 5 \mathrm{~B}^{2}$

3273 GRANIGERA] of garnbarre R5: cornberwm $B^{2}$

4033 ANFRACTVS] woge, bylkas R5: bykas B'

4135 GLAREAS] ceoslas $R 5$ : stancislas $B^{*}$

4310 FLAMINIA] sacertiadas $R 5 B^{*}$

An adjustment to Goossens's argument renders it plausible. If $\mathrm{B}, \mathrm{O}$ and ${ }^{*} \mathrm{O}$ were housed together, who could say that a scribe did not copy a hundred glosses from Brussels 1650 into the Digby apograph, whence they could have been transmitted into an archetype of the Royal brook? Yet one fact, misinterpreted by Goossens, vitiates this conclusion. In 1974 Goossens argued that the Royal glosses were copied from Brusseis after scribe $\mathrm{C}$ made alterations to the Brussels corpus, specifically after modifying glosses in HANDS A and B. His position reverses the cart and horse. Scribe $C$, in fact, systematically collated his source with $A$ and $B$ 's glosses in the Brussels $P$ div copy. Hence, glosses, partial glosses and merographs in HANDS A and B aiready corresponded to glosses in scribe C's exemplar. There are instances, for example, where the $C$ scribe added words to make Brussels agree with his own source:

2764 BIPERTITAM] i. in duas partes diuisam R5: diuisam $B^{2}$ : in duas partes B : $^{2}$. in duas partes diuisam $\mathrm{O}$

Divisam existed already in HAND A. Scribe $\mathrm{C}$ simply added in duas partes to make the texts uniform.

3652 MONARCHLAE] i. unius principatus $R 5$ : principatus $B^{2}$ : unius $B \div i$ unius principatus $\mathrm{O}$

Scribe A had already written the gloss principatus in the Brussels codex. (The word stands in other manuscripts as well.) Scribe $C$ added the term wniks to make the Brussels gloss agree with the gloss in his exemplar.

6062 SACELLA] i. templum idolorum R5: i. templa B* O: idolorum Be Again, scribe $\mathrm{C}$ collates the Brussels manuscript with his source.

* Goossens finds categorical alterations in these glosses, but there is no reason to consider these here. Altered to mowendes by scribe $C D$.

at copreomum B:. 
6178 NEGOTIVM] i. opus uel labor uel causa R5: i. labor $B^{2}$ O: i. opus uel causa $B^{c}$

Collation is evident here, as in numerous other examples.

The abundant examples of this kind of collation are enhanced by even more evidence of collation. Scribe C also altered A and B's readings and expanded their merographs, presumably to make them match those of his source:

1963 EXPEDITIONVM] fyrda $\mathrm{B}^{2}$ alt. to fyrdunga $\mathrm{B}^{\mathrm{c}}$ ( $\mathrm{R} 5$ reads fyrdwnga)

3353 DIVTVRNA] longa $\mathrm{B}^{2}$ alt to longaxa $\mathrm{B}^{c}(\mathrm{R} 5$ and $\mathrm{O}$ read longewa)

$3798 \mathrm{MACHINAS]}$ seara $\mathrm{B}^{\mathrm{a}}$ alt. to searacrafies $\mathrm{B}^{\mathrm{c}}$ (O reads searacrafias)

3944 SPVRCAE] scand $\mathrm{B}^{2}$ alt. to scandlice $\mathrm{B}^{\mathrm{c}}$ (O reads sceadlicere)

5454 INSOLESCAT] ase $\mathrm{B}^{*}$ alt. to awolige $\mathrm{B}^{\mathrm{c}}$

9965 MVSCIPVLIS] feal $\mathrm{B}^{\mathrm{b}}$ alt. to foallan $\mathrm{B}^{\mathrm{c}}$

11086 PROCERVM] ealdorman $\mathrm{B}^{\mathrm{b}}$ alt. to ealdormanna $\mathrm{B}^{\mathrm{c}}$

In the same way, $C D$ later altered some of scribe C's glosses: 1851 BELLICOSAS] 7 viglice $\mathrm{R} 5$ : wiglice $\mathrm{B}^{\mathrm{c}}$ alt. to viglice, beardlice $\mathrm{B}^{\text {cd }} .82$ Goossens now maintains - without palaeographical evidence - that some of these $C D$ alterations were made by the Royal scribel ${ }^{83}$

Evidently, if glosses in Brussels 1650 did not quite correspond to glosses in his exemplar, the $\mathrm{C}$ scribe emended them. What would he have done if the glosses did correspond? It seems likely that if glosses were already present in Brussels HANDS A and B, the glossator would not have bothered to write a duplicate. Let us rehearse the circumstances of copying. Scribe $\mathrm{C}$ comes across an apograph of Digby which he intends to collate with Brussels 1650 . The Brussels manuscript already has a few hundred glosses written in HANDS A and $B$, but this sparse glossing could be usefully augmented by such collation. Scribe $C$ begins copying glosses into Brussels, but where he finds a gloss in HAND A or B which matches one in his exemplar, he does not copy out the gloss a sccond time; he passes on. Where slight differences exist, he brings both manuscripts into conformity by correcting A or B's glosses. For this reason, glosses in three hands in Brussels (A, B and C) could correspond to a single layer in Royal 6. B. VII and need not give rise to it. ${ }^{84}$

Of course, this interpretation of events requires that a core of glosses

82 Goossens, pp. 24-5.

${ }^{83}$ Goossens, 'Alldhelm Glosses', p. 149: 'Obviously, if my assumptions are correct, CD must here be identical with the 'glossator of [RS]'.

34 The hypothesis also explains what Goossens claimed was a 'striking difference in the way [the Royal glossator] treats the glosses by $\mathrm{C}$ as compared with those by A and B' (Goossens, 'Aldhelm Glosses', p. 146). Glosses in Brussels HANDS A and B appeared 'changed fin Royal 6. B. VII] more often than not' (ibid. p. 147) than glosses in HLAND C. The corpus of glosses in HANDS A and B circulated in many other manuscripts, and probably in many divergent spellings. Such glosses might have gone unaltered by the scribe who copied from the Digby apograph. 
The transmission of the 'Digby' glosses to Aldhelm's Prosa de virginitate

represented by HANDS A and B and by elements of Hand C was present in a layer of glosses in the Digby apograph. In fact, this core of glosses circulated in almost every extant $P d v$ manuscript, and it resembled the glosses comprising the earliest gloss strata of Royal 7. D. XXIV. I call this common core of Old English and Latin glosses the 'Common Recension'. ${ }^{85}$ For present purposes, isolating the 'Common Recension' does not warrant the lengthy discussion it would require. We need only acknowledge here the working hypothesis that Brussels HANDS A and B encompassed a layer of glosses also in scribe C's exemplar.

DIFFERENCES BETWEEN GLOSSES COMMON TO BRUSSELS HAND C (FIRST STRATUM) AND ROYAL 6. B. VII (MAIN STRATUM) COMPARED TO THE LATIN GLOSS CORPUS IN DIGBY 146

Glosses in the Digby apograph plausibly resembled those common to the main glossing hand in R5 and to HANDS A, B and C in Brussels: thousands of Latin glosses alongside a few hundred Old English contributions. By the time the R5 and $\mathrm{B}^{\mathrm{c}}$ glosses were copied, however, this hypothetical Digby transcript $\left({ }^{*} \mathrm{O}\right)$ differed substantially from Digby. Theoretically, any number of intervening copies could have existed between the Digby apograph and its descendants, just as several copies of the Digby apograph could have existed. Hence, the glosses in R5 which are not found in the Digby or Brussels volumes may have been added either to the Digby apograph or to a copy of it. To avoid confusion I have not designated any intermediary manuscript copy between the Digby apograph and Royal 6. B. VII.

The transparent relationship between Royal 6. B. VII and Brussels 1650 belies occasionally stark differences between the glosses shared by $\mathrm{R} 5$ and $\mathrm{B}^{\mathrm{c}}$ and by $\mathrm{O}$. In respect to these differences, three important observations must be recorded and discussed. In the first instance, many glosses common to $\mathrm{R} 5$ and $\mathrm{B}^{\mathrm{c}}$ are neither in $\mathrm{O}$ nor in any other extant manuscript:

1930 VENENOSA] i. temperantia R5 $B^{c}$

1946 MVNICIPES] i. principes R5 Bc

1954 LATIBVLIS] i. cubilibus R5 $B^{c}$

1988 AMBRONIS] i. deuorantibus R5 $B^{c}$

2218 SE EXALTAT] i. eleuabitur R5 $B^{c}$

$2934 \mathrm{HOC}]$ pis R5 Bc

3240 IVGALITAS] s. est R5 $B^{c}$

3375 FISCALE TRIBVTVM] fiscus, i. prumptuarium cesaris inde fiscale R5 B $^{c}$

3380 DITATVS] muneratus R5 $B^{c}$

3383 PRAEDITVS] $i$. ornatus $R 5 B^{c}$

3404 MELOTE] i. mantile R5 Bc

3464 FACVNDIA] i. eloquentia R5 $B^{c}$

"8s Gwara I, pp, clvii-exciii. 


\section{Scott Gwara}

3487 THIMIAMA] i. odoramentum incensi $R 5 \mathrm{~B}^{c}$ 3531 MVNERIBVS] i. donis R5 $\mathrm{B}^{\mathrm{c}}$

3694 IMPORTVNA] i. improba R5 B B $^{\mathrm{c}}$

3697 DELERAMENTA] i. stoliditates R5 Bc

3712 EXTITISSE] i. mansisse R.5 B

These glosses are probably unique to the Digby apograph which gave rise to the Royal and Brussels HAND C corpus.

Second, many glosses common to R5 and $\mathrm{B}^{\mathrm{c}}$ diverge radically from the surviving glosses in $\mathrm{O}$, while others are only slightly different. The following random samples exemplify the degree of these differences:

906 IRRIGABAT] infundebat $R 5 B^{c}$; perfundebat $O$

1409 PROPENSIVS] diligentius $\mathrm{R} 5 \mathrm{~B}^{\mathrm{c}}$; plenius $\mathrm{O}$

1482a FRETVS] fructus R5 $B^{c}$ : functus $O$

1484 INDVSTRIA] sollertia $R_{5} B^{c}$ : curiositate $O$

1532 RATIBVS] nauibus $R 5 \mathrm{~B}^{\mathrm{c}}$ : medicinis $\mathrm{O}$

1845 FRETM fructi $R 5 B^{c}$ : functi $O$

1919 INPORTVNVS] improbus uel inmitis $R 5 \mathrm{~B}^{\text {c}}$ : ferus uel inmitis $\mathrm{O}$

1936 EXPLODATVR] excludatur uel eiciatur R5 Bc; deleatur O

2211 CONFIDVNT] consperant $\mathrm{R} 5 \mathrm{~B}^{\mathrm{c}}$ : sperant $\mathrm{O}$

2321 COMPVNGVNTVR] conpuncti $R 5 \mathrm{~B}^{\mathrm{c}}$ : constringuntur $\mathrm{O}$

3032 PROMVLGARE] statuere R5 $\mathrm{B}^{c}$ : demonstrare $\mathrm{O}$

3072 INDVSTRLA] sollertia $R_{5} B^{c}$ : assiduitate $O$

3241 AD PROPAGANDAM? ad extendendam uel protelandam R5 Bc: ad manifestandam $\mathrm{O}$

3358 HACTENVS] hucusque $R 5 \mathrm{~B}^{\mathrm{c}}$ : usque huc $\mathrm{O}$

3374 VECTIGAL] pupplica exactio R5 Bc fiscalia O

3391 REBOASSE] uociferasse $\mathrm{R}_{5} \mathrm{~B}^{\mathrm{c}}$ : tonasse $\mathrm{O}$

3392 DESCRIBITVR] memorabitur R5 Bc: memoratur O

3403 FRETVS] fructus $R 5 B^{c}$ : functus $O$

3405 INORMEM] magnum R5 $B^{c}$ : maximam $O$

3465 FRETVS] fructus $R 5 B^{\circ}$ : functus $O$

3481 GRATTSSIMVM] amantissimum R5 Bc: optatissimum O

3506 LIQVIDO manifeste $R 5 \mathrm{~B}^{\mathrm{c}}$ : clarc uel perspicue O

3543 EBDOMADIBVS] septenis uel septies $R 5$ Bc: curriculis O

3732 FERCVLORVM] epularum R5 $\mathrm{B}^{\mathrm{c}}$; diliciarum $\mathrm{O}$

3749 INORME] tam magnum $\mathrm{R}^{2} \mathrm{~B}^{\mathrm{c}}$ : inmane $\mathrm{O}$

The substitutions range from slight rewordings to utterly distinct terms, and deliberate emendation probably accounts for many of them. Infurdebat, for example, appears to have been made morphologically parallel to IRRIGABAT of 906 , just as consperant of 2211 to CONFIDVNT. Some alterations, too, represent corrections: one Digby glossator misconstrues RATIBVS (medicinis), and the mistake has been corrected to navibus. Still other readings are refinements of 
The transmission of the 'Digby' glosses to Aldhelm's Prosa de virginitate

sense. The substitution of sollertia for curiositate in 1484 INDVSTRIA privileges a superior interpretation: ' $\ldots$ cum sudoris industria efficatur antecessor'. ${ }^{86}$ The persistent quality of 'sollertia' displaces the milder 'curiositas'. Diliciarum for FERCVLORVM in 3732 ('ut ... opulentas regalium ferculorum dilicias ... in tenerrima pubertate contempserint') mischaracterizes the phrase. ${ }^{87}$ Because dilicias follows feroulorum in the text, it is an inadequate rendering. The more apposite gloss epularum therefore appears as a correction in Brussels 1650 and Royal 6. B. VII. Finally, four occurrences of FRETVS (1482a, 1845, 3403 and 3465) in which the gloss functus in O corresponds to the gloss frutus in R5 and B imply that a glossator emended to suit his own linguistic idiosyncrasies. Such alterations as these manifest a careful and intelligent editor who interpreted as he wrote. Glosses to 3241,3391 and 3405 may also show his intervention.

My third, and most important, observation raises questions of transmission. In a number of cases, glosses which are common to $R 5$ and $B^{c}$ but which are not found in $\mathrm{O}$ correspond to glosses in earlier $P d v$ manuscripts, giving the impression that they are not isolated annotations: ${ }^{88}$

\section{MANVBIAS] predas R4 S R3 C2 C1 4759 TORQVENTES] uertentes R4 S R3 C2 6312 NVGACITER] inutiliter R4 S R3 C2 C1}

These glosses which do not stem from $O$ can be explained either as accretions, or as prior contributions, to the Digby apograph. Of course, determining an exact explanation of the copying of these glosses would be fruitless. The simple fact that Brussels and Royal glosses are found in other $P d \nu$ manuscripts but not in Digby implies widespread contamination. Again and again, scribes sought to compare $P d v$ copies and to transfer glosses among them.

THE RELATIONSHIP BETWEEN GLOSSES IN BRUSSELS HAND C (SECOND STRATUM) AND THE MARGINAL GLOSSES IN DIGBY I 46

The first stratum of HAND $C$ in Brussels 1650 bears an obvious paternity. Yet a problem remains in the derivation of the second gloss stratum of $C$, which consists mainly of marginal Latin glosses and Latin glassae collectae with Old English interpretations. There is no precedent for the glassae callectae, and they were probably assembled as the scribe read the text. In almost every instance, the Old English interpretamentum derives from a gloss in HANDS A or B:

7827 DE CLATRIS] clatru pearrwe $\mathrm{B}^{\mathrm{c}}:$ pearr $<\mu>c u m \mathrm{~B}^{\mathrm{a}} \mathrm{Bs}$

7836 LASCIVVS] lasciuus gradig Bc: gradig $\mathrm{B}^{2}$

86 Ehwald 238.14: '... The] is made the leader by the effort of his labour'.

87 Ehwald 252.9-10:. . [that] they spurned the rich delights of regal feasts in their innocent youth'. ${ }^{85}$ For sigla, sce above, p. 140, n. 7 . Altered from pearricum B*. 


\section{Scott Gwara}

7837 SCORTATOR] scortator menmend $\mathrm{B}^{\mathrm{c}}$; wentwend $\mathrm{B}$ "

7838 VAGABVNDIS\} uagabundus woriend $\mathrm{B}^{c}$; moriendum $\mathrm{B}^{*}$

8102 MVNICIPIO] Municipium fasten Bc: fastene B*

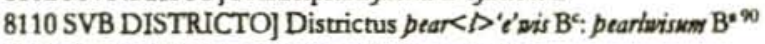

8116 A TRAMITE] tramite stige $B^{c}$ : fraw stige $B^{*}$

8152 GRASSARETVR] Geassor ic ontige B': on bigede B*

8644 ANACHORESEOS] Anachoreseos anyther $B^{c}$ : aenetes $B^{b}$

8676 STROFAM] Stropha fraus facn Bc: fanc $B^{b}$

8876 ARCHIMANDRITA] Archimandrita behfader $\mathrm{B}^{\mathrm{c}}$ : bebfeder $\mathrm{B}^{b}$

Such glosses as these demonstrate that the $\mathrm{C}$ scribe was working from the Old English glosses already present in the manuscript. The glossary entries in the margins are therefore explicable simply as points of interest.

Unlike the glossae collectae in HAND C, however, the dense marginal glossing on fols. 8-11 poses an interpretative obstacle. These glosses correspond almost word for word to marginal glosses in Digby 146 . Now, the errors we have uncovered in Royal 6. B. VII and the first layer of HAND C in Brussels show that Digby must have had dense marginal glossing before the presumed Digby apograph was penned. Otherwise, errors traceable to the intrusion of marginal glosses into the line could not have been made. Could the marginal glosses in Digby have been the source of those in the second stratum of HAND C in Brussels? The evidence is unclear, mainly because of the lack of shared error. Yet among the marginal glosses in $\mathrm{B}$ are two which could not have come from $\mathrm{O}$ :

2556 TOPAZIO] ex uirenti genere est. Topazius ornniurn gemmarum in se habet pulchritudines omnium uincit honores [Topazius .... honores om. O] Topazion lapis pretiosus in quo sicut alii adfirmant omnium colores fulgent $B^{c} \mathrm{O}$

2833 CAL_AMISTRO] Calamistro i. ac $<u>$ [aco MS] ferreo in similitudine calami[i] facto in quo crines obtorquentur ut crispi sint quem in cinere cale'sce're solent qui capillos crispant ut calamiscrati sint B⿳: Calamistratus a calamistro, i. acu ferreo in calami[s] similitudine facto in quo crines obtorquentur ut crispi sint $\mathrm{O}$

These marginal glosses are lifted from Isidore's Etymologiae, which gave rise to most of the marginal glosses in $\mathrm{O} .{ }^{91}$ In both of the cited instances, however, $\mathrm{B}^{c}$ has an additional phrase from Isidore which is not found anywhere in Digby 146. These additions might derive from the hypothetical Digby apograph, in which a scribe has added some other sections of Isidoriana where he noted unsatisfactory glosses. However, the first section in B 2556, which is missing in $\mathrm{O}$, is so similar to the second section, which is common to $\mathrm{B}$ and $\mathrm{O}$, that this hypothesis seems unlikely. The copyist of $\mathrm{O}$ would more reasonably have left

\$ 1 altered.

${ }^{91}$ Cf. M. C. Bodden, 'Evidence for Knowledge of Greek in Anglo-Saxon England', ASE 17 (1990), 217-46. 
The transmission of the 'Digby' glosses to Aldbelm's Prosa de virginitate

out extraneous material rather than resort to Isidore for further information on a term already heavily glossed. In my view, then, these marginal glosses probably stem from the same source which gave rise to the marginal glosses in $\mathrm{O}$. The errors calamii in $\mathrm{B}^{\mathrm{c}}$ and calamis in O likewise raise expectations that both sets of marginalia are related. Tentatively, then, I suggest that the second layer of Brussels glosses in HAND C derives from a text closely related to the long marginal glosses in $\mathrm{O}$.

THE DIGBY APOGRAPH (*o), CANTERBURY AND EXETER

The existence of an apograph of Digby 146 dating from c. $980 \times 1020$ and the textual transmission which I propose raise two collateral issues: where was the apograph copied, and how did it, or a version of it, get to Exeter? In answer to the first question, only one centre makes sense as the origin of the Digby apograph: Canterbury. Despite their Abingdon provenance and the meticulous sesearch of N. R. Ker, both Digby 146 and Brussels 1650 are Canterbury volumes. Exeter, then, must have applied to a Canterbury foundation for a copy of $P d v$.

To answer the second question and ascertain why and when a $P d v$ copy should have come into the possession of the Exeter farrilia, we have to speculate on Exeter's historical background as well as on the relevance of Pdv to its community. Patrick Conner's recent study of Exeter proposes two phases of intellectual activity at the late Anglo-Saxon minster. The period between 968, when Sidemann was sent to Excter with monks from Glastonbury 'to establish the new Benedictine monasticism in an important, active minster ${ }^{n / 2}$ and 1003 , when Exeter was ravaged by Swegn, witnessed a staggering intellectual reprise. This renewal is documented by an increasing number of manuscripts from about the time when Sidemann would have been promoting change at Exeter, roughly $968 \times 977$. Attributable Exeter manuscripts from this decade include traditional school authors: Amalarius, Bede, Boethius, Cassian, Hrabanus Maurus, Isidore, Persius and Prudentius. ${ }^{93}$ In my view, $P d v$ would fit into the intellectual concerns of an abbot who was trained at Glastonbury and who would have been interested in fashionable textbook authors. As I have stated elsewhere, 'Glastonbury rated as a centre of Aldhelm scholarship not only for its resources and patronage but also for its celebrated alumni. ${ }^{\text {s4 }}$ The mania for Aldhelm which was sweeping England during Sidcmann's Exeter and Crediton years can be traced directly to a coterie of Glastonbury reformers, Sidemann among them. At this historical moment, it would be fitting for Sidemann to acquire a copy of $P d v$

92 P. Conner, Anglo-Saxon Extter: a Tonth-Centwry Cultwral History (Woodbridge, 1993), p. 30.

${ }^{3}$ Ibid. pp. 3-8, iterns $12,15,17,28,31-3,46$ and 48-9.

14 Gwara, 'Manuscripts', p. 157 
from Canterbury, perhaps a generation of the Digby apograph, and to inaugurate the study of Aldhelm in his growing community. Monks in tenth-century Exeter would no doubt prize the literary sophistication which Aldhelm's auvre represented.

The second phase of intellectual growth at Exeter took place under Bishop Leofric (d. 1072), who moved the episcopal see from Crediton to Exeter in 1050. Admittedly, Leofric either obtained or produced many books, but it seems unlikely that the exemplar of Royal 6. B. VII came from Canterbury during his episcopate. Canterbury had suffered from devastation and fire first in 1011 and again in $1067,,^{95}$ and its foundations could no longer be held rich in books. Furthermore, except at Abingdon (it seems), $P d v$ had lost the pre-eminence it had long held as a model of I.atin style. An interest in Aldhelm's Latin prose could therefore be seen as antiquarian rather than current. In fact, the Exeter $P d v$ was written in the generation after Leofric's death, as if it were answering to a non-scholastic interest. The volume was probably intended to commemorate Aldhelm's sanctification in 1078 under Bishop Osmund of Salisbury. ${ }^{96}$ Around the time of Aldhelm's translation, the Exeter community probably saw fit to prepare a superior copy of $P d \nu$ from an exemplar of presumed antiquity. Thus, Royal 6. B. VII may represent the second-generation copy of the Digby apograph. Although speculative, then, it seems most likely that Exeter acquired $P d v$ from Canterbury during Sidemann's time or just afterwards and in the wake of the Aldhelm revival. Certainily the copying of $P d v$ in this era would corroborate Conner's profile of late-tenth-century Exeter as a mainstream foundation nurturing intellectual trends. ${ }^{97}$

${ }^{25}$ N. Brooks, The Eary History of the Church of Canterbury (Leicester, 1984), pp. 55-6.

* By William of Malmesbury's testimony, cf. Hamilton, Gesta pontificum, pp. 423-5.

"The preceding work derives from my Ph.D. dissertation (cited above), which incorporates an edition of all Old English and Latin glosses to the Prosa de virginitate, fully lemmatized, from the fourteen glossed manuscripts of English provenance. I owe a considerable debt to Professors A. G. Rigg and Michael Herten, who corrected innumerable mistakes and challenged me to refine points I might otherwise have left vague. I have benefited, too, from Professor David Dumville's expert advice on palaeography and dating. I am also grateful to the Dictionary of Old English, University of Toronto, for access to their microfilm manuscript archive. The Centre for Medieval Studies, University of Toronto, and the Associates of the University awarded me research grants to consult most of the Pdv manuscripts in sin. 